\title{
The Role of Traditional Workmanship in Urban Conservation of Røros, Norway
}

\author{
Giedrè Jarulaitienè, Norwegian University of Science and Technology
}

\begin{abstract}
The paper deals with the question of how changing perceptions of traditional workmanship influenced the remodelling of urban conservation policies and practices in Røros, Norway. The historical overview of shifting conservation policies revealed that varying features were attributed to the multifaceted concept of traditional workmanship. Lastly, the recently performed survey of demand for traditional workmanship in Roros indicated that present conservation practices still face challenges of industrial production due to misinterpretation of the concept of traditional workmanship.
\end{abstract}

Keywords - Mass-produced copies, urban conservation, traditional workmanship.

\section{The Success Story of Urban Conservation}

Mining town Røros was founded in the 17th century during the development of copper mining industry which was functioning for 333 years until 1977. After the closure of the mining industry, the town was inscribed on the list of UNESCO's World Heritage Sites in 1980 as the traditional way of construction was one of the features of Røros townscape which was evaluated by the criterion (IV) [1]

However, as the town's mining and agricultural activities decreased, many of the outhouses lost their original function. In 1993, ICOMOS reported, that "the emphasis in restoration seems to have been mainly on the principal buildings along the streets. Courtyards have been given less attention, and a number of outbuildings have fallen out of use and are in a state of disrepair" [2]. ICOMOS recommended that "existing building elements, such as windows, doors and wall boards should, where possible, be conserved and repaired rather than replaced. Traditional techniques and materials should be given priority in new works" [2]. Consequently, the Outbuilding Project was launched in 1994 and the responsibility for carrying the project out was delegated to Røros municipality.

The primary goal of the project was to repair approximately 400 outbuildings by using traditional materials and techniques. Despite that, as a secondary outcome, the Outbuilding Project created a special environment for traditional craftsmen to operate within the field of heritage conservation. The efforts were crowned by winning the Europa Nostra Prize in 2015 for building good mutual relations between the state institutions and private owners, as well as establishing a platform for self-employed craftsmen, because of the high level of responsibility deputed to individual craftspeople in planning and implementing the repairs. Thus, the focus on traditional workmanship resulted not only in the fortunate urban conservation model but also in internationally awarded success.

Even though it is commonly believed that the presented success story of urban conservation in Røros was enabled after receiving the status of World Heritage Site, this paper argues that the focus on traditional workmanship has deeper roots in the history of urban conservation of Røros. The paper also analyses how the concept of traditional workmanship has changed during time and how this change influenced the transformation of urban landscape (Fig. 1).

\section{Røros Traditional Townscape in the Age of} Romantic Nationalism of the 19th Century

The first well known written source with a description of Røros townscape dates back to 1734, when Swedish botanist Carl von Linné travelled from Sweden crossing the border to Norway and compared natural and cultural landscapes. Røros was defined as a small town composed of simple one-storey dwellings with no gardens attached $[3,111]$. The following scientific descriptions of Røros from the 18th and the first half of the 19th centuries have contributed as historical documents of the changing townscape of Røros. These descriptions were also used in the beginning of the 20 th century as sources of reference by the first antiquarians in order to validate the restoration of "the true image of Røros".

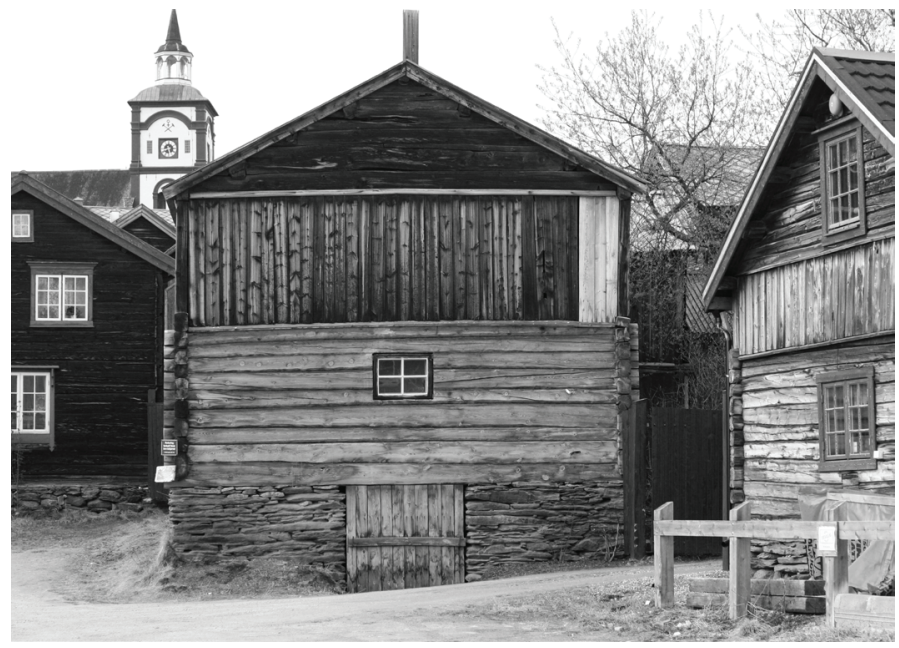

Fig. 1. The marks of traditional workmanship influence the urban landscape of Røros (Photo taken by Giedre Jarulaitiene, 2011). 


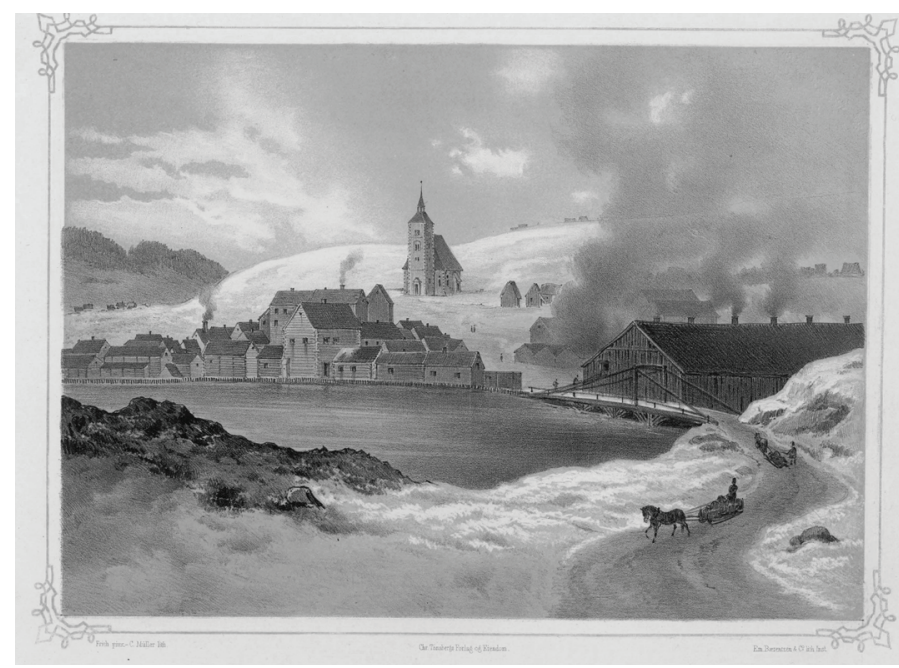

Fig. 2. "Røros represents a sad sight for a traveller; the barren area in the high mountains is enhanced by the Copper Works smoke-filled environment and the grey winter sky" $[4,163]$. (Lithography by C. Müller, 1848).

Towards the middle of the 19th century, the descriptions of Røros changed the character from aiming at scientific observations to the rise of national awareness. Røros townscape was assessed by sensual, mostly by visual aesthetical criteria at that time and these writings were the sign of the Romantic Nationalism (Fig. 2).

The Movement of Romantic Nationalism spread out in Germanic countries. It originated from Johann Gottfried Herder's idea that geography formed natural economy and customs of people, so every nation is distinguishable by its climate, language, traditions and heredity. Folk traditions and folklore were revealed as creative forces of a nation, as well as the importance of the gothic architecture for German national awareness was discovered under the influence of J. G. Herder [5, 242] and was transferred to Norway by Norwegian painter Johan Christian Dahl, who worked in Dresden and Leipzig. J. Ch. Dahl contributed in founding the Society for the Preservation of Norwegian Ancient Monuments (Fortidsminneforeningen) in 1844 according to the German model.

The building traditions in Røros were not considered interesting at that period as it represented the cultural decline, which according to Nicolay Nicolaysen, the leader of the Society for the Preservation of Norwegian Ancient Monuments (1851-1899), began in the end of the 18th century, when the classical architectural styles of masonry from southern Europe were repeated in wooden architecture. Even the prevalence of the new style from Swiss mountains, which reached Norway through Germany in the second half of the 19th century, as the secondary outcome of building the railway system, was not considered that harmful by N. Nicolaysen, as this architectural style was suitable exceptionally for wooden buildings $[6,48]$. The fact that Swiss chalet style was actualized by means of advanced industrial workmanship was not considered as regretful.
III. The Fight Against Industrial Architectural Styles by Industrial Means in the 1st Half of the 20 th Century

After the establishment of the Directorate for Cultural Heritage (Riksantikvaren) in 1912, the focus of antiquarians shifted towards studies and preservation of the traditional urban buildings, not only country side farms, but structures from posterior date, then the medieval times, as well. These changes were inspired by one of the first national antiquarians Harry Fett (1913-1946).

H. Fett is famous for his speech Bergstadspreken-Glück Auf in 1939 at the annual meeting of the Society for the Preservation of Norwegian Ancient Monuments and the National Norwegian Museum Society (Norske Museers Landsforening) in Røros where he advocated for preservation of the heritage of the mining town and encouraged to further develop and use the living traditions of local craftsmanship. He promoted the creation of new forms of cultivating old traditional workmanship [7, 28-30] and maintained that cultural values should not end up in museum, but should be kept in their original environment and that the assignment of heritage conservationists is different from that of museologists and lies in emphasizing the continuity of life and traditions.

H. Fett engaged in conservation work at Røros, as for him "Røros is of another cultural category. The whole town is one of Norway's best-preserved monuments to trade. This is a town of Mercury's artists" [8, 41]. Fett viewed the history of the nation as dependent on exchange: "travel and trade, towns and villages, arts and crafts, production and cultivation of the country's resources. $<\ldots>$ Contrary to his nationalist predecessors, H. Fett provocatively praised the absolute monarchy that reigned in the seventeenth and eighteenth centuries for its political and military art, its classical ideals, its literature and not least, its architecture" [9, 23-24]. While H. Fett's predecessors viewed the classical structures as "un-national" and "untrue" in contrast to the authentic, natural and free Norwegian culture, the opposite approach of Fett enabled to recognize the Røros town as worth preserving because it testified the periods of the 17th and 18th century and the foreign initiatives in copper works and trade.

The ideological program of Fett was implemented in practice by the main architect of the National Directorate for Cultural Heritage - Halvor Vreim. During H. Vreim's period, between the years 1937-1967, the industrial Swiss chalet style was considered as a threat to original townscape and Vreim advocated the method of restoration or reversal (tilbakeføring) back to the solid, hand-crafted, traditional structures and façades. The main goal was to achieve the stylistic "pre-1850s' appearance" or the "true image of Røros", when the classical styles were prevailing and the mining industry experienced its golden age.

During H. Vreim's period the restoration works at Røros followed the ideal of "unity of style" as the main goal was the stylistic unity of the townscape and variations in details were sacrificed for the sake of general esthetical appearance. However, the methods against the industrially produced building elements were industrial as well and the restorations were made by any means, be it cast concrete in place of natural stone, clay or lime 


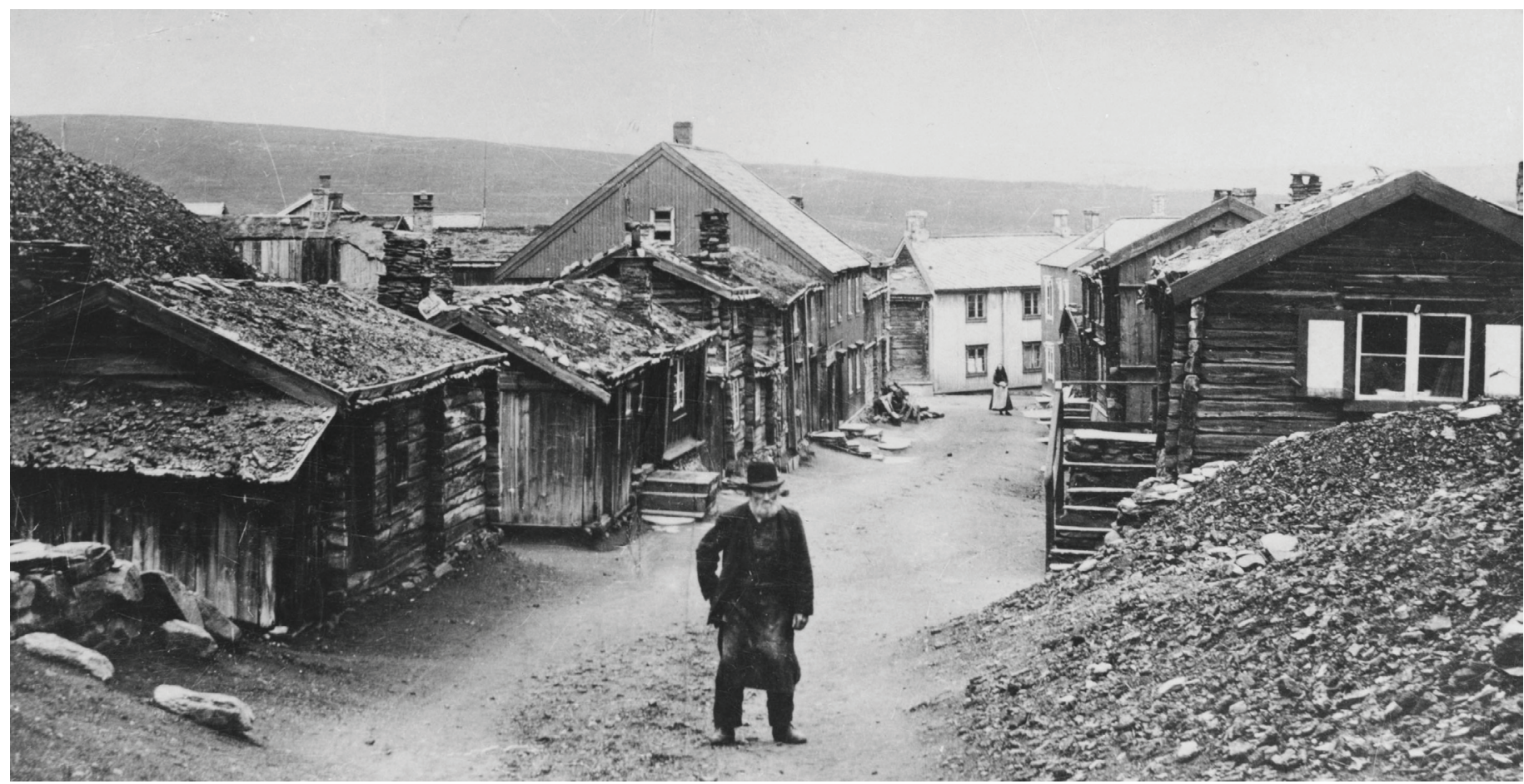

Fig. 3. The introduction of Swiss chalet style (Sleggveien 3) in traditional townscape of Røros (Photo taken by Iver Olsen, 1908 CRørosmuseet).

mortar, fiber cement roofing instead of stone slates. Thus, the modern materials and industrial workmanship was accepted as long as the exterior appearance corresponded to "the true image of Røros” [10, 420-422].

IV. The Local Initiatives for Heritage Protection at Røros in the 2nd Half of the 20th Century

In the second half of the 20th century, Røros heritage management developed into another level due to many reasons, one of them being the adoption of the regulation plan for the centre of Røros in 1976, which was administered mainly by the local municipality and widened the scope from preservation of particular listed buildings to large urban environment. Another reason was the internationalization of local heritage by inscribing the historical town centre into UNESCO's world heritage list in 1980. In 1989 the decentralization of national heritage management was implemented by dividing responsibilities between national, regional and local institutions according to the developed legal apparatus. Røros museum was a supplementary local institution which also gained an important role in preserving buildings and documents of the Røros Cooper Works after its closure in 1977.

The most important contribution of employees of Røros museum belongs to Sverre Ødegaard, whose studies of building traditions in Røros, as well as his writings and practical work in the field of heritage preservation marked the paradigm shift in the protection of cultural heritage. Even though both H. Vreim and S. Ødegaard justified restorations, ideally to pre-1850s' state, they had different enemies, this time it was post-war modernism instead of the Swiss chalet style, which was no longer considered as threatening [11, 77]. The major difference between the two generations was the growing awareness of the historical layers of buildings which enrich its authenticity and therefore should not be erased as devaluating traces of later times.

The Swiss chalet style house at Sleggveien 3 could be named as one of many examples as it marks the controversial history of heritage preservation in Røros. The dwelling house was originally built in the middle of the 19th century in the notched log construction as a traditional Røros dwelling house, with a tiny sleeping loft over a living room and kitchen, similar to the neighbouring houses at Sleggveien. The house was completely rebuilt in 1908 in a Swiss chalet style (Fig. 3) and in the beginning of the 1950-ties the façade facing the courtyard underwent major transformations by removing windows and adding a balcony in the post-war modernism style [12, 7]. Due to the "declined" workmanship performed during reparations, the National Directorate for Cultural Heritage gave the permission for demolishing, but the permission was withdrawn in 1994 and the house was all of a sudden included in the temporary cultural heritage list and in 2005 , the protection was affirmed. Consequently, the building was recognized as a valuable heritage object after considerable time span passed from the major transformations and the "declined" architectural styles and workmanship were not considered as worthless anymore [13, 156] (Fig. 4).

However, the restoration of buildings into their original or "traditional" appearance was still the prevailing practice in Røros in the second half of the 20th century, but this time the restoration works had to be based on scientific evidence and documentation. 


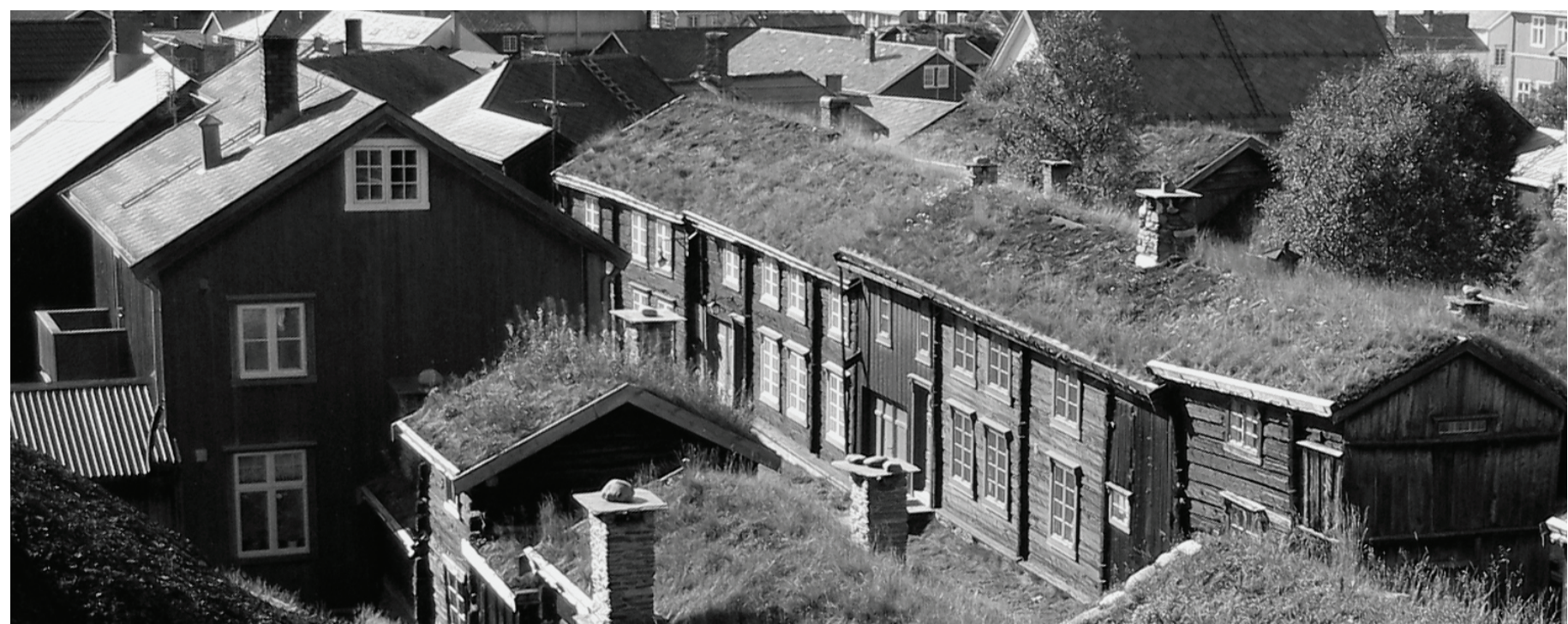

Fig. 4. The dwelling-house (Sleggveien 3) in the left corner of the picture was considered as of pour quality and was decided by the National Directorate for Cultural Heritage to be demolished in the 1950-ties as it ruined the "true image of Røros" by creating the dissonance to its surroundings. (Photo taken by Giedre Jarulaitienè, 2008).

S. Ødegaard launched a long and overwhelming research project on building traditions in Røros in order to provide scientific evidences for various decisions in heritage preservation.

In the beginning of the $1970 \mathrm{~s}, \mathrm{~S}$. Ødegaard wrote reports on management of conservation works in Røros and concluded that there is a lack of collaboration between the local authorities towards the common purpose of heritage preservation and proposed a plan of joining all kinds of conservation activities at Malmplassen. It took some time for the first heritage conservator to be employed at municipal level in 1988, so until then the Røros museum played an important role as a bridge between the local population and the National Directorate for Cultural Heritage as well as a prophet of conservation ideas in Røros.

With a financial backup from County's antiquarian office Ødegaard initiated the opening of the Antiquarian Workshop (Antikvarisk Verksted) at Kurantgården in 1974, which employed local craftsmen with special knowledge in traditional workmanship and materials. The Antiquarian Workshop was organized as a private company related to the museum and specializing at restoration works. The leading carpenter at the workshop was Kåre Løkken and the company specialized in producing copies of windows, doors, moldings and other building details for heritage objects placed not only at Røros, but in other parts of the country as well.

The need for the use of traditional workmanship in practice was also realized at Røros municipality, which established a position for local carpenter and carver Håkon Borgos with a financial support from the National Directorate for Cultural Heritage in 1969. He performed restoration works at many urban farms in Røros in cooperation with $\mathrm{S}$. Ødegaard as his supervisor [14, 249]. Due to administrative contradictions, the official position was withdrawn after a couple of years.
In 1988, the official position of local antiquarian was established at the municipality and architect Ulrich Malisius received the position. He reacted against still prevailing practice of shifting original building details instead of repairing them and therefore he advocated the starting of a systematic work in changing the handworkers' convictions. He initiated regular handworkers' meetings in order to share experience and discuss the operating problems. Malisius' goal was to raise the handworkers' awareness of their own work and self-reflectiveness. The Antiquarian Workshop was proposed as a platform for such handworkers' forums $[15,121]$. The practice of monthly handworkers' gatherings has survived until today and contributed to expanding the workshop's functions and developing the Building Preservation Centre (Bygningsvernsenteret) at Røros museum with the Antiquarian Workshop incorporated as part of the centre.

\section{The Origins of Outbuilding Project in the Reproduction of Medieval Workmanship}

The already mentioned ICOMOS report of 1993 and the stated criticism towards the state of outbuildings after their original function had vanished, resulted in the creation of Outbuilding Project (Uthusprosjektet). Before the beginning of the project in 1996, the carpenters, who had already participated at the national Medieval Project (Middelalderprosjektet) were invited to Røros in order to give ten weeks training for 15 craftsmen. In that way the experience and knowledge of the participants of the Medieval Project was transferred to the craftsmen in Røros [16, 51].

The Medieval Project was initiated by the National Directorate for Cultural Heritage and lasted from 1991-1998. The purpose of the project was to repair the profane medieval buildings in poor condition by copying the workmanship and processing building materials with traditional tools. The leader of the Medieval Proj- 
ect from the National Directorate for Cultural Heritage Anders Haslestad emphasized the difference between the modern and traditional workmanship, the viewpoint which was influenced by Swedish architect Ove Hidemark [17, 112]. O. Hidemark is considered as the creator of ideological approach in the Nordic countries promoting the restoration works without any modern techniques or materials, when all the work was done according to the same method and appropriate materials, which had been common and traditional at that time when the withdrawn building detail had been processed.

In a more general sense, the traditional workmanship for O. Hidemark is not necessarily medieval, but rather opposite to the modern one, and lasted from approximately the year 1000 to around the year $1950[18,6]$. Even though the tradition changed, for example from use of manual pit saws and the introduction of water-powered sawmills with up-and-down saws in the 16th century to the spread of circular saws in the 19th century, these alterations are rather accepted as the developing tradition, however, contemporary building materials such as cement and aluminium gutters were not considered as part of building traditions. The reason for such rationale depends on many factors, such as technical incompatibility between the new modern and old traditional materials, the use of mass-produced imported products instead of locally hand-made building elements and local materials etc.

\section{Is there Demand for the Established Supply of Traditional Workmanship in Røros?}

Despite enormous attempts of national and local antiquarians in creating the traditional handworkers' environment in Røros, the practice of using industrially produced copies "in old style" is still prevailing among the owners of old wooden buildings in Røros. The demand for such products influenced the supply and resulted in creation of such "traditional" products as "Røros windows" and "Røros doors" in modern factories.

After surveying the demand for traditional workmanship among the owners of old wooden buildings it was clarified, that most of the recent reparations involved changing of windows and, according to the respondents - "the new ones were made to look the same as the previous ones". However, $100 \%$ of all new windows installed by respondents were produced at the local factory Røros Bruk $A S$ which brags itself for producing traditionally looking windows, though fabricated in the most modern production line of windows in Europe [19].

Today, when the antiquarian values are more often market-determined [20, 174], the question should be raised using the open market terminology and reasoning. Further challenge therefore still appears to be unsolved by the antiquarians in creating the demand for the traditional workmanship among the inhabitants of Røros, while the supply for it is secured.

Another trial for antiquarians might emerge in the near future of urban and building conservation if the inlayed modern mass-produced building elements become valuable building elements, worthy to be conserved. The question remains open whether the same preservationist ethics of making procedurally authentic copies should be applied when these modern mass-produced building elements are concerned. The replication of the advanced processes and means of production, which were once considered as industrial and modern, but have become out of date today, are a bigger challenge in comparison with the reproduction of low-tech procedures.

\section{REFERENCES}

1. Røros Mining Town and the Circumference [online]. UNESCO World Heritage List [cited: 21.06.2015]. http://whc.unesco.org/en/list/55

2. Larsen, K. E. Evaluation of Røros Bergstad in Norway, World Heritage Convention. Oslo: ICOMOS, Den norske nasjonalkomitte, 1994.

3. Linné, C., Gullander B. Linné i Dalarna : Carl Linnaeus dagbok från resan i Dalarna 1734 med åtskilliga stycken ur hans dalska och lapska floror, ur hans Diaeta naturalis, Flora oeconomica, ur brev m. m. / en antologi sammanställd av Bertil Gullander. Stockholm: Forum, 1980, p. 111.

4. Asbjørnsen, P. C., Tonsberg C. Norge fremstillet i Tegninger. Christiania: Christian Tønsberg, 1848, p. 163.

5. Jokilehto, J. History of architectural conservation. Oxford: Butterworth-Heinemann, 2002, p. 242.

6. Christensen, A. L. Kunsten å bevare. Om kulturminnevern og fortidsinteresse i Norge. Oslo: Pax, 2011, p. 48.

7. Fett, H. Glück auf. En Bergstadspreken på Røros. Oslo: Kunst og kultur, 1939 , p. 28-30.

8. Fett, H. Continuity (1949). Future Anterior, Vol. VII, No. 2, 2010, p. 41.

9. Aavitsland, K. B. From Nationalism to Cosmopolitan Classicism. Harry Fett's Concept of Cultural Capital. Future Anterior, Vol. VII, Nr. 2, 2010, p. 23-24. https://doi.org/10.1353/fta.2010.0023

10. Bye, M. Histories of architectural conservation: five case studies on the treatment of Norwegian vernacular heritage buildings circa 1920-1980. Trondheim: Norwegian University of Science and Technology, 2010, p. $420-422$.

11. Bye, M. Røros og kulturminnevernet frem til 1980. Røros-refleksjoner etter 30 år som verdensarv [E. Gjeldsvik, ed.]. Oslo: Pax, 2014, p. 77.

12. Brænne, J. B.f. 359. Røros. Sleggveien 3. Farge- og bygningsarkeologiske undersøkelser og dokumentasjon av øst- og sydfasadene. NIKU Oppdragsrapport 175/2014, p. 7.

13. Engen, E., Fjeldheim O. H., Kulturminner - et verdispørsmål. Røros refleksjoner etter 30 år som verdensarv [E. Gjeldsvik, ed.]. Oslo: Pax, 2014, p. 156

14. Bye, M. Røros og kulturminnevernet frem til 1980. Røros-refleksjoner etter 30 år som verdensarv [E. Gjeldsvik, ed.]. Oslo: Pax, 2014, p. 249.

15. Gjelsvik, E. Lokal kulturminneforvaltning 1988-2000. Røros-refleksjoner etter 30 år som verdensarv [E. Gjeldsvik, ed.]. Oslo: Pax, 2014, p. 121

16. Andersen, S., Brænne, J. Kulturminne-forvaltningens og planarbeidets historie på Røros: Kulturarv og verdiskaping. Økonomiske virkninger av kulturarven på Røros. Arbeidspakke 1. Oslo: NIKU, 2006, p. 51.

17. Fjeldheim, O. H. Riksantikvarens middelalderprosjekt: vernefilosof formet i tre. Arbok. Oslo: Foreningen til norske fortidsminnesmerkers bevaring, 2012, p. 112

18. Hidemark, $\mathbf{O}$. Traditionell byggnadsteknik - marginalkunskap eller baskunskap. Kulturmiljövärd. No. 2-3, 1994, p. 6.

19. Hindklev, B. T. Røros Bruk i teten [online]. Fjell-Ljom [cited 22.08.2015]. http://www.fjell-ljom.no/?vis artikkel=true\&id=2329

20. Christensen, A. L. Kunsten å bevare. Om kulturminnevern og fortidsinteresse i Norge. Oslo: Pax, 2011, p. 174 


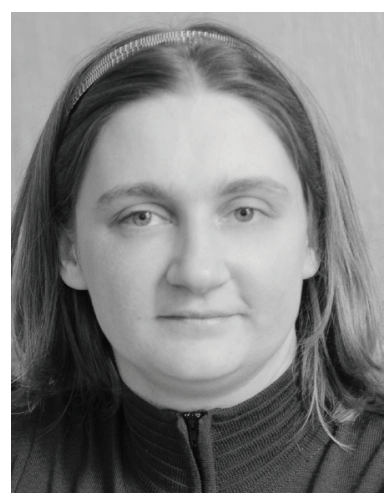

Giedrè Jarulaitienè is a $\mathrm{PhD}$ fellow with the Norwegian University of Science and Technology. She is conducting a research project on the role of traditional workmanship in the field of heritage conservation. The research project is a comparative analysis of use, demand and supply of traditional workmanship in historical urban environments. Giedré Jarulaitienè obtained the Master degree in Heritage Management and the Bachelor degree in Cultural History and Social Anthropology from Vilnius University, Lithuania.

Giedrẻ Jarulaitienè actively participates in practical implementation of international projects on sharing the experience of traditional workmanship in heritage conservation financed by the EEA and Norway grants.

\section{Contact Data}

\section{Giedrẻ Jarulaitienė}

E-mail: giedre.jarulaitiene@ntnu.no 